\title{
SEKWENCYJNOŚĆ A WIELOPOZIOMOWE ZARZĄDZANIE GOSPODARKĄ ZE SZCZEGÓLNYM UWZGLĘDNIENIEM PAŃSTW ROZWIJAJĄCYCH SIĘ
}

Związki między sekwencyjnością a zarządzaniem procesami, które zachodzą na kilku poziomach, są dość oczywiste, jeśli prześledzić te procesy historycznie, oraz widoczne w wielu działaniach podejmowanych współcześnie. Płaszczyzny, na których można te związki prześledzić, to procesy: 1) zachodzące w poszczególnych państwach; 2) dotyczące rozwiązań, które pomagają, a często umożliwiają rozwijanie kontaktów międzynarodowych między państwami; 3) zachodzące w różnych konfiguracjach i skali państw - bilateralne, subregionalne, regionalne i międzynarodowe w szerszej skali; 4) globalne. Osobno możemy rozpatrywać dziedziny, w których obserwuje się zmiany wynikające z sekwencji kontaktów międzynarodowych i ich wpływ na ewolucję zastosowanych rozwiązań. Dziedziny te obejmują: tworzenie prawa, instytucji, infrastruktury, szkolnictwa, lecznictwa, rozwój warunków dla biznesu, rozwój administracji lokalnej, regionalnej, centralnej, więzi międzynarodowych, które mają wpływ na działanie wymienionych dziedzin. Towarzyszy temu rozwój struktur politycznych i sceny politycznej z partiami, instytucjami politycznymi, a także rozwiązaniami prawnymi i systemem kontroli. Odrębnym problemem jest system finansowy $z$ instytucjami finansowymi, przepisami i zasadami działania rynku finansowego.

\section{Wielopoziomowe zarządzanie i sekwencyjność w praktyce stosunków międzynarodowych}

Wiele $\mathrm{z}$ wymienionych rozwiązań ma swoje umocowanie prawne i instytucjonalne na szczeblu międzynarodowym: globalnym lub regionalnym. Oznacza to, że na szczeblu państwa posługujemy się pewnymi rozwiązaniami, które są uniwersalne, a więc stosowane we wszystkich państwach. Przykładem takiego rozwiązania jest chociażby polityka kursowa, reżim kursowy i wymienialność waluty każdego państwa członkowskiego MFW. Zasady wymienialności określone są w zgodzie 
$\mathrm{z}$ art. VIII statutu MFW. Reżimy kursowe określone są w ramach teoretycznych, których uczymy się podczas wykładu z ekonomii czy finansów. W ostatnich trzech dziesięcioleciach byliśmy świadkami przejścia od różnych odmian reżimów kursowych opartych na rozwiązaniach, które służyły do usztywniania kursu, do reżimów, które stopniowo wiązały ze sobą kursy walut, by wreszcie zastąpić rozwiązania o sztywnym charakterze reżimem kursu płynnego, który stał się powszechnie obowiązujący.

Jako pierwsze posunięcie w tym kierunku można uznać decyzję prezydenta USA Richarda Nixona, który w sierpniu 1971 r. podjął decyzję o odejściu dolara amerykańskiego od parytetu wyrażonego w złocie. Za decyzją amerykańską wcześniej czy później podążyły inne państwa, wprowadzono to wówczas jako rozwiązanie na zintegrowanych rynkach, np. w Unii Europejskiej. Choć w tym ostatnim przypadku nie nazwano wprowadzonego rozwiązania „po imieniu”, wyraźnie interpretując podjętą w tym zakresie decyzję polityczną. Decyzja w tym zakresie zapadła podczas szczytu w Amsterdamie i towarzyszyła przyjęciu przez państwa członkowskie Traktatu amsterdamskiego. Była to jedyna decyzja dotycząca bezpośrednio sfery gospodarczej. Pozostałe decyzje dotyczyły reform instytucjonalno-prawnych w kontekście perspektywy kolejnego, bezprecedensowego poszerzenia o państwa pokomunistyczne Europy Środkowej i Wschodniej, które nastąpiło w 2004 i następnie 2007 r. Decyzja Komisji Europejskiej o poszerzeniu pasma wahań kursów europejskiego mechanizmu kursowego $z+4,5$ do $+15,0 \%$ może być uznana za odejście od sztywnego kursu. Wydarzenie to nie było nagłaśniane. Przeszło - można powiedzieć - bez echa, kiedy scena polityczna skupiona była na przyjmowaniu rozwiązań odnoszących się do instytucji i reprezentacji w nich państw członkowskich. De facto poszerzenie pasma wahań dla kursów walut ze skali $9 \%$ na $30 \%$ z pewnością może być uznane za taką decyzję. Do sprawy szerokości wahań kursu walut europejskich nigdy potem nie wracano. Euro kształtuje swój kurs, tak jak wszystkie inne waluty świata, wobec dolara amerykańskiego. Waluta odniesienia ma płynny kurs, co wymaga podobnego rozwiązania od pozostałych walut.

Wiele państw hołdowało zasadzie stosowania sztywnego kursu. Jeszcze pod koniec lat 90. takie rozwiązania stosowano w państwach Azji czy Ameryki Łacińskiej. Sztywny kurs był również rozwiązaniem stosowanym we wstępnych fazach transformacji w państwach Europy Środkowej i Wschodniej. W tej grupie państw sztywny kurs był uzasadniony ze względu na wpływ tego rozwiązania na politykę stabilizowania gospodarki w sferze ograniczenia stopy inflacji. Skutkiem stosowania sztywnych kursów jest zawsze to, że kurs danej waluty waha się w zdefiniowanym przedziale o określonym dolnym i górnym pułapie wahań, co ma swoje dobre i złe 
strony. Dobrą stroną jest wspomniana rola sztywnego kursu w ograniczaniu inflacji. Za korzystne w tym rozwiązaniu można również uznać i to, że sztywny kurs zwiększa jego przewidywalność, co ma określone znaczenie dla biznesu, a także tworzenie dobrego środowiska dla inwestycji spekulacyjnych. W momencie zbliżania się kursu do górnej lub dolnej granicy można oczekiwać interwencji, co oznacza odwrócenie tendencji w kształtowaniu się kursu i tworzy idealne warunki dla inwestorów, którzy z tego zwrotu korzystają. Ten sam warunek oznacza, że sztywny kurs to dobry klimat dla spekulacyjnych transakcji na rynku kapitałowym. Sam Soros w przeszłości stwierdził, że swój majątek pomnożył z dużą łatwością w warunkach sztywnego reżimu kursowego.

Ostatnimi państwami, które odeszły od sztywnego reżimu kursu, były państwa azjatyckie i Ameryki Łacińskiej oraz Rosja z państwami WNP. Decyzja o odejściu od sztywnego kursu w tych gospodarkach nastąpiła w efekcie kryzysu finansowego 1997/1978. Przejawem tego kryzysu były szybkie zmiany poziomu kursu, co dość często wiązano z dużymi strumieniami przepływów kapitału do gospodarek regionu Azji. Nie była to jednak przyczyna tego kryzysu. Żadne z państw regionu nie zamknęło swego rynku w efekcie kryzysu dla napływu kapitału. Przyczyn było kilka. Jedną z nich był sztywny kurs i spekulacje na kursach. Drugą - niewydolny, nieprzystosowany do dynamiczniej rozwijającego się rynku kapitałowego system bankowy. Trzecią było wejście w fazę wykorzystania rosnącego poziomu efektywności wykorzystania czynników produkcji bez wcześniejszego wykorzystania rezerw prostych w tym zakresie, zakumulowanych w ilości czynników produkcji. Te stwierdzenia wskazują na pewną sekwencyjność, którą można określić jako sekwencyjność rozwoju.

\subsection{Gospodarki rozwinięte i wschodzące}

Obecnie dość swobodnie definiujemy poszczególne grupy państw. To samo odnosi się do określenia „świat zachodni” czy „Azja”. Świat zachodni utożsamia się z rozwojem i demokracją, przestrzeganiem praw człowieka. Nie wszystkie te cechy są spełniane przez państwa zaliczane do rozwiniętych, zachodnich, czy nawet demokratycznych. W opracowaniu nie chodzi o ocenę przyjętych klasyfikacji ani o próbę ich poprawy. Chodzi tu raczej o pokazanie dynamizmu pewnych procesów, przy równoczesnej trudności wprowadzenia ostrych klasyfikacji i podziałów.

Rozpoczęcie dowodu wymaga w takiej sytuacji przedstawienia definicji co się rozumie pod pojęciem „świata zachodniego", a co pod pojęciem „Azji”? Zarówno w pierwszym, jak i w drugim przypadku mamy do czynienia z dość zróżnicowanymi pod względem rozwoju gospodarkami. Geograficzne położenie nie zawsze wskazuje, że dana gospodarka jest zaliczana do państw azjatyckich, zwłaszcza gdy ma 
wiele cech, które każą ją utożsamiać z krajami wysoko rozwiniętymi, dość mechanicznie określanymi jako „świat Zachodu” lub członkowie OECD. Świat Zachodu to pojęcie typowo obejmujące państwa w układzie subregionalnym, o czym decyduje fakt, że włączamy tu USA i Kanadę, państwa europejskie (wraz z państwami, które dołączyły do UE w 2004 r. oraz w następnych poszerzeniach w 2007/2008 i 2013 r.), ponadto wymienia się tu bez wahania Japonię, Australię i Nową Zelandię. Państwa te reprezentują wysoki, ale nader zróżnicowany poziom rozwoju, co rzutuje na ich możliwości finansowania różnych podejmowanych w nich przedsięwzięć, rozwój infrastruktury, edukacji, finansowanie badań rozwojowych, lecznictwa itp. Różnice te przenoszą się również, co jest oczywiste, na wielkości skumulowanego przez państwa długu publicznego i rolę instytucjonalnych inwestorów na rynku kapitałowym. Stwarza to różne możliwości dla rozwoju rynku kapitałowego, a co za tym idzie możliwości rozwoju infrastruktury bankowej, ubezpieczeń, biznesu.

Przykładowo udział zakumulowanych inwestycji instytucjonalnych w większości państw OECD w latach 1995-2007 wzrósł 2-3-krotnie. Najwyższy wskaźnik zakumulowanych inwestycji instytucjonalnych do PKB w grupie państw OECD ma Irlandia (555,3\%), następnie USA (211,2\%), Wielka Brytania (202,5\%), Islandia $(198,1 \%)$, Holandia (196,9\%), Dania $(181,3 \%)$ i Francja $(171,4 \%)^{2}$. Najniższe wskaźniki w grupie państw OECD w tym samym zakresie odnotowano w Turcji (4,4\%), Meksyku (9,7\%), Grecji (15,3\%), Słowacji (16,2\%), Czechach (22,4\%), Polsce $(30,1 \%)$, na Węgrzech $(32,9 \%)$ i w Norwegii $(61,9 \%)$. Średnia wartość inwestycji instytucjonalnych w stosunku do PKB w państwach OECD w 1995 r. wynosiła $110,2 \%$, podczas gdy w 2007 r. - 162,6\%3․ W tym miejscu warto podkreślić, że inwestycje instytucjonalne są angażowane $\mathrm{w}$ fundusze emerytalne, ubezpieczenia i fundusze inwestycyjne. Ograniczone zaangażowanie w wymienionych sferach ogranicza rozwój rynku kapitałowego, co ma duży wpływ na rozwój rynku pracy i tworzenie miejsc pracy, wpływając pośrednio i bezpośrednio na płynność systemu emerytalnego ${ }^{4}$. W tej grupie państw również bardzo duże różnice wystąpiły w zakresie możliwości finansowania działań interwencyjnych podczas kryzysu 2008/2009+, co ilustruje tabela $1^{5}$.

${ }^{1}$ E. Gonnard, E. Jung Kim, I. Ynesta, Recent Trends in Institutional Investors Statistics, OECD, Paris 2008, s. 4.

2 Ibidem.

3 Ibidem.

${ }^{4}$ R. Della Croce, F. Stewart, J. Yermo, Promoting Longer-term Investment by Institutional Investors: Selected Issues and Policies, OECD, Paris 2011, s. 4.

5 Tabela 1 nie odnosi się wyłącznie do grupy państw członkowskich OECD, ale obejmuje również państwa, których nie zalicza się do grupy najbardziej rozwiniętych, o czym umownie decyduje członkostwo w tej organizacji. 
Tabela 1. Kwoty planowane na działania interwencyjne w latach 2008-2009

\begin{tabular}{|l|r|r|l|c|c|}
\hline \multicolumn{1}{|c|}{ Państwo } & $\begin{array}{c}\text { Kwota } \\
\text { w mld USD }\end{array}$ & \% PNB & \multicolumn{1}{c|}{ Państwo } & $\begin{array}{c}\text { Kwota } \\
\text { w mld USD }\end{array}$ & \% PNB \\
\hline Arabia Saudyjska & 126,7 & 3,4 & Malezja & 17,2 & 4,0 \\
\hline Argentyna & 3,9 & 1,2 & Meksyk & 11,4 & 1,0 \\
\hline Australia & 10,1 & 0,9 & Niemcy & 103,3 & 1,6 \\
\hline Austria & 3,7 & 0,6 & Norwegia & 2,9 & 0,6 \\
\hline Belgia & 2,5 & 0,6 & Nowa Zelandia & 5,0 & 3,7 \\
\hline Brazylia & 3,6 & 0,2 & Pakistan & 7,6 & 1,9 \\
\hline Chile & 4,0 & 2,2 & Peru & 3,2 & 1,1 \\
\hline ChRL & 586,0 & 6,9 & Polska & 31,4 & 5,5 \\
\hline Czechy & 7,8 & 1,9 & Portugalia & 2,7 & 1,3 \\
\hline Egipt & 5,4 & 1,7 & Rosja & 20,0 & 1,1 \\
\hline Filipiny & 6,1 & 1,2 & RPA & 3,7 & 1,2 \\
\hline Finlandia & 2,6 & 1,7 & Singapur & 13,9 & 3,5 \\
\hline Francja & 33,0 & 1,3 & Szwajcaria & 1,3 & 0,3 \\
\hline Hiszpania & 113,3 & 6,7 & Szwecja & 1,0 & 3,0 \\
\hline Holandia & 7,5 & 1,0 & Tajlandia & 8,5 & 3,3 \\
\hline Indie & 4,0 & 0,3 & Tajwan & 12,0 & 3,0 \\
\hline Indonezja & 6,7 & 1,3 & USA & 787,0 & 5,5 \\
\hline Islandia & 2,1 & 5,3 & Węgry & 6,5 & 4,0 \\
\hline Izrael & 5,0 & 2,7 & Wielka Brytania & 36,3 & 0,9 \\
\hline Japonia & 110,0 & 2,3 & Wietnam & 1,0 & 1,1 \\
\hline Kanada & 43,6 & 0,7 & Włochy & 6,3 & 0,3 \\
\hline Korea Płd. & 10,8 & 1,1 & Świat ogółem & 2180,6 & 3,5 \\
\hline
\end{tabular}

Źródło: I. Ortiz, Fiscal Stimulus Plans. The need for a new global deal, MFW 2010.

Z przedstawionego zestawienia wynika duże zróżnicowanie udziałów w PNB kwot przeznaczonych na interwencję podczas kryzysu, jak i wielkość samych kwot przeznaczonych na działania interwencyjne. Do grupy państw o dużych wydatkach interwencyjnych $\mathrm{w}$ gospodarce szacowanych $\mathrm{w}$ wartościach bezwzględnych można zaliczyć: USA, Chiny, Hiszpanię, Japonię czy Niemcy. Najniższe kwoty na cele interwencyjne przeznaczyły: Szwecja, Wietnam, Szwajcaria, Islandia, Belgia czy Brazylia. Analizując sytuację finansową (wielkość deficytów budżetowych w stosunku do PNB czy długu publicznego do PNB), poziom rozwoju, wielkość kraju, liczbę ludności i jego PNB, widzimy, że nie tylko możliwości finansowe decydowały o wielkościach kwot przeznaczonych na działania interwencyjne. W większości przypadków decydowały o tym założenia polityki gospodarczej. 
Informacje te prowadzą nas do wniosku, że świat zachodni jest „trudny do zdefiniowania" mimo dość częstego stosowania tego określenia, jego skład może podlegać redefiniowaniu i jest płynny. Ogólnie pod tym pojęciem rozumiemy państwa wysoko rozwinięte, z pewnością obejmuje to państwa europejskie, ale już i tu mamy duże różnice w dochodach per capita (Luksemburg, Niemcy i Rumunia, Bułgaria). Z pewnością grupa ta obejmuje USA, Kanadę i Japonię. Zalicza się do niej również Australię i Nową Zelandię. Członkami OECD są także Meksyk i Turcja.

Uzupełnieniem listy państw OECD, która już sama w sobie może budzić kontrowersje, jest uwzględnienie gospodarek, które zalicza się do najbardziej konkurencyjnych. Piszę to, zdając sobie w pełni sprawę z tego, że pojęcie konkurencyjności gospodarki jest pojęciem mało precyzyjnym ${ }^{6}$, chociaż ocena konkurencyjności oparta jest na relatywnie dobrze przygotowanych do tego celu wskaźnikach, szczegółowo analizowanych i porównywanych w skali międzynarodowej. Uwzględnienie $\mathrm{w}$ tych rozważaniach państw $\mathrm{z}$ listy najbardziej konkurencyjnych ma uzasadnienie z dwóch powodów:

- po pierwsze, pokaże wyraźnie rozbieżności między grupą państw OECD, wskazując równocześnie, że nawet analizy oparte na matematycznie wyliczonych wskaźnikach, przy zastosowaniu tej samej metodologii, mogą nie być obiektywne;

- po drugie, pokaże, co różni tę grupę państw od pozostałych, które będą definiowane $\mathrm{w}$ dalszej części opracowania; ta informacja będzie nam dalej potrzebna do udowodnienia jednej z tez o silnych więziach współzależności w gospodarce światowej i wynikających z nich wspólnych interesach.

Tabela 2. Państwa zaliczane do grupy, w której podstawową siłą napędową gospodarki są innowacje

\begin{tabular}{|c|c|c|c|c|c|c|c|}
\hline Lp. & Państwo & Lp. & Państwo & Lp. & Państwo & Lp. & Państwo \\
\hline 1 & Australia & 10 & Hiszpania & 19 & Luksemburg & 28 & Stowenia \\
\hline 2 & Austria & 11 & Holandia & 20 & Malta & 29 & Szwecja \\
\hline 3 & Belgia & 12 & Hongkong & 21 & Niemcy & 30 & Szwajcaria \\
\hline 4 & Cypr & 13 & Irlandia & 22 & Norwegia & 31 & Tajwan \\
\hline 5 & Czechy & 14 & Islandia & 23 & Nowa Zelandia & 32 & USA \\
\hline 6 & Dania & 15 & Izrael & 24 & Portugalia & 33 & Wielka Brytania \\
\hline 7 & Finlandia & 16 & Japonia & 25 & Puerto Rico & 34 & Włochy \\
\hline 8 & Francja & 17 & Kanada & 26 & Singapur & 35 & Zjedn. Emiraty Arabskie \\
\hline 9 & Grecja & 18 & Korea Płd. & 27 & Stowacja & & \\
\hline
\end{tabular}

Źródło: Na podstawie Global Competitiveness Report 2012-2013, Geneva 2012, s. 10.

${ }^{6}$ P. Krugman, Competitiveness. A Dangerous Obsession, „Foreign Affairs” March/April 1994, Vol. 73, No. 2. 
Liczba państw zaklasyfikowanych do tej grupy wynosi 35 i wykazuje tendencję wzrostową. W Raporcie 2008-2009 liczba państwa w grupie najbardziej zaawansowanych wynosiła $34^{7}$. Nowym państwem na liście jest Słowacja. Większe zmiany obserwuje się na pozostałych listach, wskazujących wcześniejsze fazy przemian i przygotowania do zaawansowanego rozwoju. W dalszej części podane zostaną bardziej szczegółowe charakterystyki, które każda z gospodarek grupy powinna spełniać, aby zostać do tej grupy zakwalifikowana.

Tabela 3. Państwa w fazie przejściowej, w której siłą napędową gospodarki jest wydajność, a fazą wyższą, innowacyjną

\begin{tabular}{|c|c|c|c|c|c|c|c|}
\hline Lp. & Państwo & Lp. & Państwo & Lp. & Państwo & Lp. & Państwo \\
\hline 1 & Argentyna & 7 & Estonia & 13 & Meksyk & 19 & Turcja \\
\hline 2 & Bahrajn & 8 & Kazachstan & 14 & Oman & 20 & Urugwaj \\
\hline 3 & Barbados & 9 & Liban & 15 & Polska & 21 & Węgry \\
\hline 4 & Brazylia & 10 & Litwa & 16 & Rosja & & \\
\hline 5 & Chile & 11 & Łotwa & 17 & Seszele & & \\
\hline 6 & Chorwacja & 12 & Malezja & 18 & Trynidad & & \\
\hline
\end{tabular}

Źródło: Jak do tabeli 1.

Lista państw w tej fazie rozwoju w latach 2008-2009 była krótsza o 6 państw w porównaniu z listą z lat 2012-2013, kiedy było już ich 21. Na liście znalazły się Argentyna, Brazylia, Kazachstan, Malezja, Meksyk, Oman, Seszele - 7 państw, które w okresie 2008-2009 notowane były jako państwa na etapach fazach rozwoju. Z notowań wypadł Katar, który odnotowany był w fazie przejściowej między drugim a trzecim etapem rozwoju, najwyższym w Raporcie 2008-2009.

Jak widać, różne zbiory państw o podobnych cechach są zbiorami łącznymi, a nie rozłącznymi, jeśli zastosować określenia stosowane w matematyce. To nachodzenie na siebie poszczególnych zbiorów oznacza wspólne elementy i utrudnia ostre podziały. Stanowi również podstawę wspólnych interesów i współzależności. Ta łączność zbiorów widoczna jest zwłaszcza między państwami Europy - USA i państwami azjatyckimi. Jest tak, chociaż długoletnie istnienie wielkiej triady: USA - EWG/UE - Japonia uległo ewolucji. Po pierwsze, zamiast 2 państw i organizacji integracyjnej możemy wymienić $\mathrm{NAFTA}^{8}$ - UE - ASEAN ${ }^{9}$, przy czym zamiast UE możemy wprowadzić

7 Global Competitiveness Report 2008-2009, Geneva 2008, s. 9.

${ }^{8}$ NAFTA - strefa wolnego handlu między USA, Kanadą i Meksykiem.

9 ASEAN - Stowarzyszenie Narodów Azji Południowo-Wschodniej. Powstało w 1967 r. Członkami są: Brunei, Kambodża, Indonezja, Laos, Malezja, Myanmar, Filipiny, Singapur, Tajlandia, Wietnam. 
$\mathrm{EOG}^{10}$, a ASEAN może być zastąpiony przez ASEAN+5/6 ${ }^{11}$. Warto wyjaśnić, że np. Korea Płd. jest stowarzyszona z UE i tworzy strefę wolnego handlu z USA.

Przedstawiony obraz, nawet tylko wycinka powiązań instytucjonalnych, które liberalizują wymianę handlową między państwami trzech wymienionych ugrupowań, wskazuje, że kontakty gospodarcze między wymienionymi rynkami są rozbudowane. Fakt ten z jednej strony pozwala zdefiniować geograficznie państwa świata zachodniego i Azji, co jednak nie oznacza, że część państw azjatyckich nie tworzy świata zachodniego. Tak można bowiem klasyfikować Japonię, Koreę, Singapur czy Tajwan oraz Hongkong.

Zresztą, jeśli spojrzymy na definicję pojęcia „świat zachodni” historycznie, to okazuje się, że ewoluowało ono również w historii, poczynając od czasów starożytnych, przez średniowiecze, odrodzenie, nowożytność, do współczesnego. Obecnie dynamika tej ewolucji ponownie ulega przyspieszeniu.

\subsection{Identyfikacja pozostałych państw i poziomu ich rozwoju}

Używając geograficznych definicji regionów, obok świata zachodniego i Azji mamy państwa Ameryki Łacińskiej i państwa Afryki. Oba regiony są bardzo zróżnicowane pod względem rozwoju, podobnie jak obserwowano to w grupie zaliczanej do świata Zachodu, jak i do państw Azji. Oba regiony są również w różnym stopniu wewnętrznie zintegrowane. Poza instytucjonalnymi rozwiązaniami regionalnymi, które mogą wpływać na ich integrację, mamy tu wiele powiązań zewnętrznych, które dają dostęp do rynków eksportowych. Część z umów instytucjonalizujących powiązania zewnętrzne jest już zawarta, inne są negocjowane. W obu regionach obserwujemy duży wpływ instytucjonalnych więzi z UE, a także poleganie na państwach, które reprezentują wyższy poziom rozwoju w regionie. Przykładowo państwa Afryki Subsaharyjskiej obserwują wydarzenia i rozwiązania zastosowane w regionie Afryki Północnej. Ważny dla koncepcji ich rozwoju jest przykład awansu gospodarczego i politycznego RPA czy Libii. W Ameryce Południowej obserwujemy podobne zjawisko. Państwa Mercosur obserwują Chile, a także zmiany zachodzące w Brazylii czy Argentynie.

$\mathrm{Na}$ obu kontynentach obserwuje się duże zróżnicowanie pod względem rozwoju. Obok państw, które zaliczymy do gospodarek wschodzących, mamy państwa

${ }^{10}$ EOG - Europejski Obszar Gospodarczy łączący rynek UE i EFTA, wprowadzając między nimi cztery swobody obowiązujące w UE (transferu towarów, usług, ludzi i kapitału). EOG powstał w 1994 r. jako etap przygotowujący państwa EFTA do członkostwa w UE oraz tworzący warunki do bliższej współpracy między UE a państwami, które nadal pozostały członkami EFTA.

11 ASEAN obudowany jest siecią stref wolnego handlu: z Australią i Nową Zelandią (od $2010 \mathrm{r}$.), Chinami (2010 r.), Indiami (2010 r.), Japonią (2008 r.), Koreą Płd. (2010 r.). Strefa wolnego handlu z UE jest $\mathrm{w}$ procesie negocjacji. Coraz więcej mówi się również o potrzebie utworzenia strefy wolnego handlu między USA a ASEAN, traktując takie rozwiązanie jako strategiczny ruch ze strony USA. http://investvine.com/ us-calls-for-asean-free-trade-agreement/, dostęp 20.08.2013. 
rozwijające się i państwa określane mianem upadłych. W tych ostatnich brak jest struktur politycznych, które mogłyby gwarantować prowadzenie stabilnej polityki wewnętrznej czy też doprowadzić do wykorzystania powiązań instytucjonalnych zewnętrznych do rozwoju. Zmiany na liście państw o słabych strukturach państwowych podawane są w rocznych raportach przygotowywanych przez Found for Peace ${ }^{12}$.

W literaturze przyjęto podział państw o słabych strukturach politycznych na cztery kategorie ${ }^{13}$ :

- państwa słabe: Boliwia, Ekwador, Gujana, Gwatemala, Paragwaj, Burkina Faso, Czad, Ghana, Gwinea, Madagaskar, Malawi, Mali, Niger, Nigeria, Republika Środkowoafrykańska, Białoruś, Gruzja, Kirgistan, Liban, Mołdawia, Tadżykistan, Birma, Filipiny, Laos, Papua-Nowa Gwinea, Sri Lanka, Timur Wschodni, Wyspy Salomona,

- państwa upadające: Haiti, Kolumbia, Wybrzeże Kości Słoniowej, Zimbabwe, Irak, Indonezja, Korea Płd., Nepal,

- państwa upadłe: Demokratyczna Republika Konga, Liban, Sierra Leone, Sudan, Afganistan,

- państwa o całkowitym zaniku państwowości: Somalia ${ }^{14}$.

Przedstawioną listę państw z problemami warto uzupełnić informacją na temat stadiów rozwoju poszczególnych państw.

Tabela 4. Państwa w drugiej fazie rozwoju, w której czynnikiem dominującym jest efektywność czynników produkcji

\begin{tabular}{|c|c|c|c|c|c|}
\hline Lp. & Państwo & Lp. & Państwo & Lp. & Państwo \\
\hline 1 & Albania & 11 & Gwatemala & 22 & Paragwaj \\
\hline 2 & Armenia & 12 & Indonezja & 23 & Peru \\
\hline 3 & Bośnia i Hercegowina & 13 & Jamajka & 24 & RPA \\
\hline 4 & Butgaria & 14 & Jordania & 25 & Rumunia \\
\hline 5 & Chiny & 15 & Kolumbia & 27 & Serbia \\
\hline 6 & Czarnogóra & 16 & Kostaryka & 28 & Suazi \\
\hline 7 & Dominikana & 17 & Macedonia & 29 & Surinam \\
\hline 8 & Ekwador & 18 & Maroko & 30 & Tajlandia \\
\hline 9 & Grecja & 19 & Namibia & 32 & Ukraina \\
\hline 10 & Gruzja & 20 & Panama & 33 & Wyspy Zielonego Przylądka \\
\hline
\end{tabular}

Źródło: Jak do tabeli 1.

12 http://library.fundforpeace.org/fsi13-overview, dostęp 19.07.2013.

${ }_{13}$ Na podstawie: N. Chomsky, Failed States: The Abuse of Power and the Assault on Democracy, Henry Hold and Company, New York 2007, s. 39-79; A. Ghani, C. Lockhart, Fixing Failed States: A Framework for Rebuilding a Fractured World, Oxford University Press, Oxford and New York 2009, s. 7-85.

${ }_{14}$ G. Mills, J.P. Pham, D. Kilcullen, Fixing Africa's Most Failed State, (Kindle Edition), Tafelberg, New York 2013. 
Raport z 2008 r. zawierał 27 państw, które oceniano jako rynki osiągające drugi etap rozwoju, w którym decydującą rolę w rozwoju odgrywa efektywność wykorzystania czynników produkcji.

Tabela 5. Państwa w przejściowej fazie rozwoju między fazą pierwszą a drugą, w której dostępność czynników produkcji jest zastępowana efektywnością ich wykorzystywania

\begin{tabular}{|c|c|c|c|c|c|}
\hline Lp. & Państwo & Lp. & Państwo & Lp. & Państwo \\
\hline 1 & Algieria & 7 & Egipt & 13 & Kuwejt \\
\hline 2 & Arabia Saudyjska & 8 & Filipiny & 14 & Libia \\
\hline 3 & Azerbejdżan & 9 & Gabon & 15 & Mongolia \\
\hline 4 & Boliwia & 10 & Honduras & 16 & Sri Lanka \\
\hline 5 & Botswana & 11 & Iran & 17 & Wenezuela \\
\hline 6 & Brunei & 12 & Katar & & \\
\hline
\end{tabular}

Źródło: Jak do tabeli 1.

Liczba państw w fazie przejściowej z pierwszej do drugiej w obu raportach 2008 i 2012-2013 jest taka sama. Niemniej jednak zawiera ona kilka państw, które w 2008 r. były jeszcze w fazie pierwszej. Są to m.in. Algieria i Egipt.

Tabela 6. Faza pierwsza rozwoju, w której decydującą rolę odgrywa dostępność czynników produkcji

\begin{tabular}{|c|c|c|c|c|c|}
\hline Lp. & Państwo & Lp. & Państwo & Lp. & Państwo \\
\hline 1 & Bangladesz & 14 & Kenia & 27 & Pakistan \\
\hline 2 & Benin & 15 & Kirgistan & 28 & Rwanda \\
\hline 3 & Burkina Faso & 16 & Lesotho & 29 & Senegal \\
\hline 4 & Burundi & 17 & Liberia & 30 & Sierra Leone \\
\hline 5 & Czad & 18 & Madagaskar & 31 & Tadżykistan \\
\hline 6 & Etiopia & 19 & Malawi & 32 & Tanzania \\
\hline 7 & Gambia & 20 & Mali & 33 & Uganda \\
\hline 8 & Ghana & 21 & Mauretania & 34 & Wietnam \\
\hline 9 & Haiti & 22 & Mołdawia & 35 & Wybrzeże Kości Stoniowej \\
\hline 10 & Indie & 23 & Mozambik & 36 & Zambia \\
\hline 11 & Jemen & 24 & Nepal & & \\
\hline 12 & Kambodża & 25 & Nigeria & & \\
\hline 13 & Kamerun & 26 & Nikaragua & & \\
\hline
\end{tabular}

Źródło: Jak do tabeli 1. 
Z grupy pierwszej ubyło 6 państw w latach 2008-2012/2013. Spadek liczby państw znajdujących się w pierwszej fazie rozwoju oznacza skokowe zmiany w gospodarce kilku z nich. Przykładami najlepiej to ilustrującymi mogą być Egipt i Honduras.

W każdym z wymienionych etapów rozwoju inne znaczenie dla jego dynamiki ma inny zestaw czynników. Pokazanie różnic w tym zakresie wyjaśnia, że państwa znajdujące się na różnych etapach rozwoju mają wzajemnie komplementarne wobec siebie gospodarki. Awans na wyższy etap rozwoju państw pokonujących lukę rozwoju jest tym szybszy, im większy jest udział w ich kontaktach zewnętrznych - z gospodarkami zaawansowanymi gospodarczo. Było to widoczne zwłaszcza podczas uzyskiwania członkostwa w UE przez państwa pokomunistyczne.

\section{Rysunek 1. Etapy rozwoju i czynniki decydujące o dynamice pokonywania luki rozwojowej}

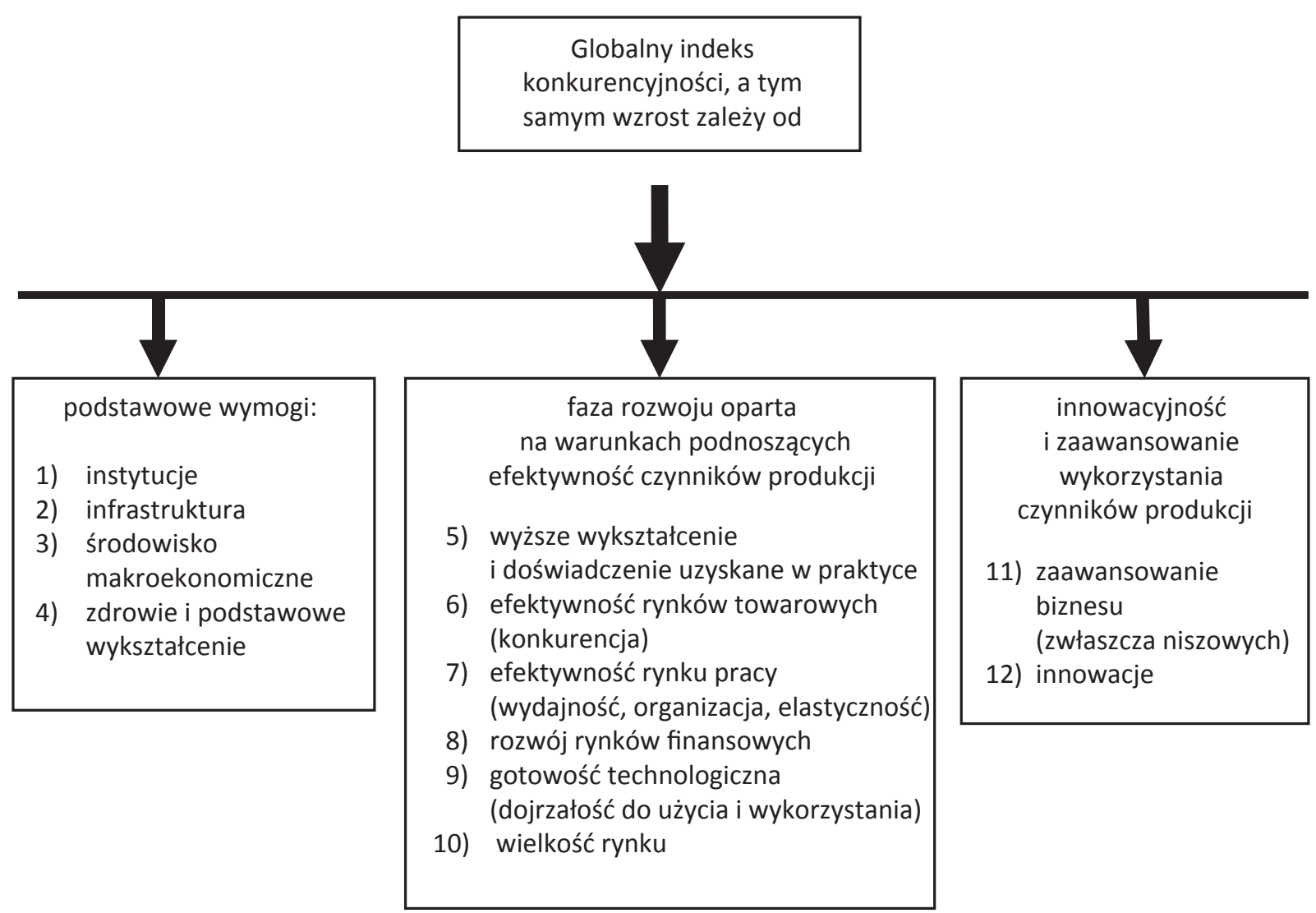

\begin{tabular}{|c|c|c|}
\hline $\begin{array}{c}\text { Podstawowe dla gospodarki } \\
\text { stymulowanej przez ilość } \\
\text { dostępnych czynników } \\
\text { produkcji }\end{array}$ & $\begin{array}{c}\text { Ważne dla fazy rozwoju } \\
\text { stymulowanej przez } \\
\text { podnoszenie wydajności } \\
\text { czynników produkcji }\end{array}$ & $\begin{array}{c}\text { Zasadnicze dla gospodarki } \\
\text { stymulowanej przez } \\
\text { innowacje }\end{array}$ \\
\hline
\end{tabular}

Źródło: Na podstawie Global Competitiveness Report 2012-2013, Geneva 2012, s. 8. 
Trzy, a w praktyce pięć przedstawionych grup państw zostało do swoich grup zaklasyfikowanych na podstawie szczegółowej analizy wskaźników, które pokazują, co w ich gospodarkach odgrywa decydującą rolę dla rozwoju, jaki jest poziom rozwoju infrastruktury, poziom wykształcenia ludności, decydujący o jakości zasobów pracy, wydajności, płacach itp. Zestawień tych dokonałam celowo, gdyż pokazują one, że poszczególne grupy państw nie mają sprzecznych ze sobą interesów, a raczej dążą do współpracy, która może być dla nich wszystkich korzystna, jeśli jest tak zorganizowana, że ogranicza wyzysk i sprzyja tworzeniu dobrobytu we wszystkich grupach państw. Koncepcja ta zostanie dalej rozwinięta i wsparta dodatkowymi argumentami.

Tabela 7. Wagi elementów decydujących o rozwoju na poszczególnych jego etapach oraz przedziały poziomu płac

\begin{tabular}{|l|c|c|c|c|c|}
\hline \multicolumn{1}{|c|}{ Wyszczególnienie } & \multicolumn{5}{|c|}{ Fazy rozwoju } \\
\hline $\begin{array}{l}\text { Parametry } \\
\text { charakteryzujące }\end{array}$ & $\begin{array}{c}\text { I stymulowana przez } \\
\text { zasoby czynników } \\
\text { produkcji }\end{array}$ & $\begin{array}{c}\text { przejściowa } \\
\text { z I do II }\end{array}$ & $\begin{array}{c}\text { II stymulowana } \\
\text { przez wydajność }\end{array}$ & $\begin{array}{c}\text { przejściowa z II } \\
\text { do III }\end{array}$ & $\begin{array}{c}\text { II innowacyjna } \\
\text { i zaawansowana }\end{array}$ \\
\hline $\begin{array}{l}\text { PKB przedziały } \\
\text { per capita w USD }\end{array}$ & $<2000$ & $2000-2999$ & $3000-3999$ & $9000-17000$ & $>17000$ \\
\hline $\begin{array}{l}\text { Wagi dla } \\
\text { podstawowych } \\
\text { wymogów }\end{array}$ & 60 & $40-60$ & 40 & $20-40$ & 20 \\
\hline $\begin{array}{l}\text { Wagi dla warunków } \\
\text { podnoszacych } \\
\text { wydajność }\end{array}$ & 35 & $35-50$ & 50 & 50 & 50 \\
\hline $\begin{array}{l}\text { Wagi dla czynników } \\
\text { innowacyjnych } \\
\text { i zaawansowanych }\end{array}$ & 5 & $5-10$ & 10 & $10-30$ & 30 \\
\hline
\end{tabular}

a Wartości określone w parytecie siły nabywczej.

Źródło: Jak do tabeli 2, s. 9.

Zestawienie wskazuje na występowanie w gospodarce światowej warunków do angażowania się w inwestycje zagraniczne. Zróżnicowanie rozwoju niesie za sobą zróżnicowanie w kwalifikacjach, rozwoju infrastruktury i zdolności zarządzania (jakość instytucji). Dodatkowym czynnikiem decydującym o zainteresowaniu przepływem inwestycji są różnice w poziomie stóp procentowych. Zgodnie z zaleceniami MFW stopy procentowe powinny kształtować się na takim poziomie, który odzwierciedla stan zaopatrzenia danego rynku w kapitał. Oznacza to wysokie stopy procentowe na rynkach o ograniczonych zasobach kapitału oraz niskie stopy na rynkach nasyconych kapitałem.

Różnice w stopach procentowych mogą skutecznie warunkować przepływ kapitału, z zastrzeżeniem, że rynek o względnie wysokich stopach procentowych 
charakteryzuje się zespołem cech określonych w zestawieniu wymogów dla pierwszego etapu rozwoju, a więc ma odpowiednią infrastrukturę, instytucje, zasoby pracy $\mathrm{z}$ minimalnym podstawowym wykształceniem. Kryteria te dodatkowo uzupełniają warunki członkostwa w MFW, BŚ i WTO. W praktyce decyduje to o stanie finansów państwa oraz szerokości otwarcia jego gospodarki i warunkach do inwestowania. Zasadniczo warunki dla inwestorów zagranicznych powinny być wyrównane $\mathrm{z}$ warunkami dla inwestorów krajowych.

Infrastruktura stopniowo rozwijała się wraz z inwestycjami towarzyszącymi wydobyciu surowcó $w^{15}$. Przepisy prawne i instytucje podlegały harmonizacji wraz $\mathrm{z}$ zaawansowaniem programów realizowanych $\mathrm{w}$ ramach członkostwa $\mathrm{w}$ organizacjach międzynarodowych oraz współpracy z UE. W tej części określono grupy państw, zdefiniowano je pod kątem poziomu rozwoju. Stanowi to punkt wyjścia do określenia interesów poszczególnych grup państw i odpowiedzi na pytania dotyczące tego, czy interesy te są komplementarne, czy też wzajemnie ze sobą konkurują, wywołując konflikty.

\section{Stan rozwoju i metody wielopoziomowego zarządzania}

Im niższy jest poziom rozwoju, tym większy może być wpływ otoczenia międzynarodowego na dynamikę rozwoju takiej gospodarki. Niemniej jednak gospodarka czy państwo, które chce zrobić użytek z zewnętrznych kanałów oddziaływania, powinno spełnić kilka kryteriów, w tym przede wszystkim odpowiednie przygotowanie instytucjonalno-prawne, infrastrukturalne oraz edukacyjne ludności do nowego etapu rozwoju, w którym tworzy się warunki do szybkiej ewolucji struktur, instytucji i gospodarki, a także zmian w zakresie przygotowania ludności od strony edukacyjnej, zdrowotnej i psychologicznej. Wszystkim tym zmianom musi towarzyszyć akceptacja społeczna, bez której trudno jest zakładać zarówno poparcie działań podejmowanych przez polityków, jak i ich skutków.

Prześledzenie listy regionów i położonych w nich państw, które podjęły wysiłek zmian systemowych, wejścia na ścieżkę wzrostu i dołączenia do głównego nurtu gospodarki światowej, pozwala na stwierdzenie, że wcześniej postawiona na ten temat teza znajdzie silne poparcie w praktyce przeprowadzonych tam zmian i powodzeniu

${ }^{15}$ Informację na ten temat można znaleźć w dwóch kolejnych raportach UNCTAD nt. inwestycji zagranicznych z lat 2007 i 2008 (World Investment Report. Transnational Corporations, Extractive Industries and Development 2007; World Investment Report. Transnational Corporations and the Infrastructure Challenge 2008). 
zastosowanej strategii. Postawione tezy zilustrowane zostały doświadczeniami państw z peryferii Europy Zachodniej (Grecji, Portugalii i Hiszpanii), państw Europy Środkowej i Zachodniej, państw powstałych z rozpadu b. ZSRR, co obejmuje zarówno państwa Europy Wschodniej, jak i państwa Azji Centralnej. W grupie tych państw obserwuje się dość zasadnicze różnice w przyjętych strategiach transformacyjnych i ich skuteczności oraz samodzielności polityki. Odrębnych wniosków dostarcza doświadczenie państw Azji, gdzie część z nich - np. Japonia - dołączyła do głównego nurtu gospodarki światowej w latach 60., wykorzystując silne wsparcie USA. Inne było tu doświadczenie „małych tygrysów azjatyckich” (Tajwan, Singapur, Korea Płd., Hongkong), a jeszcze inne Indii czy bardziej współcześnie Chin (ChRL), Wietnamu, Laosu i Kambodży. Wreszcie całkowicie odmienne są doświadczenia różnych państw Ameryki Łacińskiej, wystarczy tu wymienić Meksyk, Chile, Brazylię i Argentynę czy Kostarykę. Przemiany w państwach Afryki Północnej nie zostały zakończone, ale wydarzenia od grudnia $2010 \mathrm{r}$. wskazują, że jest to dopiero początek wieloletniego i kompleksowego procesu zmian społeczno-gospodarczych.

Współczesne doświadczenia dotyczące zmian w systemie politycznym Hiszpanii, Grecji czy Portugalii były związane z perspektywą członkostwa w EWG. System gospodarczy ewoluował, dopasowując się do wymogów integracji europejskiej, a także do procesów zachodzących szerzej, na poziomie globalnym (jak np. kwestia wprowadzenia wymienialności waluty zgodnie $\mathrm{z}$ warunkami sformułowanymi w art. 8 statutu MFW, czy w przypadku handlu i rozwiązań dotyczących rynku zgodnie z założeniami liberalizacji podjętymi w ramach GATT). Głębsze zmiany wymagane były w przypadku rewolucji 1989 r. w krajach Europy Środkowej i Wschodniej. W tym przypadku zmianom podlegały dwa systemy: polityczny i gospodarczy. Kapitałem, który był w stanie wspomagać te zmiany, były kwalifikacje ludzi. Silnym ograniczeniem były braki w sferze zarządzania i przedsiębiorczości. Niemniej jednak lukę w tym zakresie w wielu państwach regionu dość szybko udało się wypełnić, w czym ważną rolę odegrała praktyka, a nie teoretyczne przygotowanie. Inaczej sprawa przedstawia się jeśli idzie o państwa basenu Morza Śródziemnego, które zaszeregowano dla uproszczenia jako państwa Afryki Północnej. W ich przypadku ograniczeń było więcej i obejmowały one zarówno sferę polityczną, jak i gospodarczą oraz społeczną. Jednym z zasadniczych ograniczeń były niedostatki dostaw żywności, co spowodowało wzrost cen produktów spożywczych i rolnych, za czym przyszło załamanie procesów. Niemniej problem ten powróci, czemu sprzyja znaczny rozwój przepływu informacji dotyczącej sposobu organizowania się, domagania się swoich praw bez rozlewu krwi i ofiar. Takich form komunikowania się i napływu informacji, która stanowi podstawę dla porównań warunków „tam” i „tu”, nie było nigdy na tak dużą skalę i tak łatwo pozyskiwanych. Te nowe warunki można uznać za silny stymulator 
wydarzeń oraz czynnik sprzyjający organizowaniu masowych i bezkrwawych protestów, których byliśmy świadkami w tym regionie. Część z państw w regionie nie uniknęła bezkrwawych zmian polityków, niemniej pierwsze działania podejmowano w zgodzie z zasadą „braku agresji” i , użycia siły”. Początek dały wydarzenia w Tunezji, za która poszedł Egipt (dwukrotne demonstracje i wrzenia społeczeństwa), za czym podążyły Libia i Jemen. Obywatelskie powstania miały również miejsce w Bahrajnie i Syrii. Na mniejszą skalę obserwowano protesty rodzące się w Algierii, Iraku, Jordanii, Kuwejcie, Maroku i Sudanie. O demonstracjach w małej skali można też mówić jeśli idzie o Mauretanię, Oman, Arabię Saudyjską, a także Dżibuti, Saharę Zachodnią i Autonomię Palestyny.

\subsection{Kanały wielopoziomowego zarządzania}

Wielopoziomowe zarządzanie obejmuje różne struktury instytucjonalne i stanowi konsekwencje przyjętych w nich uzgodnień oraz akceptację ich przez każde państwo członkowskie w procesie dołączania do danej organizacji. Organizacje międzynarodowe w większości zajmują się wycinkiem działalności gospodarczej, która ma wpływ na decyzje podejmowane w ramach polityki narodowej danego państwa. Przykładowo MFW określa warunki, na jakich prowadzona jest polityka wymienialności kursu danej waluty, podczas gdy UE w ramach polityki wynikającej z Paktu Stabilności i Wzrostu zajmuje się polityką makrostabilizacyjną państw członkowskich UE. Podczas kryzysu instrument ten został wzmocniony przez politykę prowadzoną w ramach tzw. semestru europejskiego. Dodatkowym instrumentem oddziaływania są coroczne raporty UE nt. makrostabilizacji. Polityka państw członkowskich powinna również uwzględniać priorytety zawarte w Strategii Europa 2020.

W większości przypadków działania podejmowane w ramach tych posunięć mających na celu koordynację polityki państw członkowskich mają charakter otwarty. Jednakże niespełnienie wymogów może powodować określone konsekwencje. W Komisji Europejskiej m.in. planowano ograniczenie transferów z budżetu ogólnego UE jako „karę” za brak realizacji wytycznych dotyczących makrostabilizacji. Nie podjęto jednak decyzji w tym zakresie. Oznacza to, że stosowaną karą będą nadal zapisy dotyczące zwiększonych depozytów państw, wobec których prowadzone jest postępowanie stabilizacyjne. Mechanizm zastosowany w UE dość dobrze pokazuje, jakie możliwości istnieją w zakresie wielopoziomowego koordynowania polityki. Równocześnie jednak praktyka państw członkowskich UE wskazuje, że skuteczność przyjętych rozwiązań jest bardzo zróżnicowana. Niemniej jednak statystyki Eurostatu wskazują, że Grecja i pozostałe państwa mające kłopoty w zakresie makropolityki poprawiają swoje wyniki. Oznacza to, że przyjęte rozwiązania mogą być skuteczne, 
zwłaszcza gdy wsparte są kredytami, które ułatwiają uzyskanie płynności finansowej przez podmioty, a także wprowadza się szereg dodatkowych uwarunkowań i instytucje (jak np. MFW), które są bardziej rygorystyczne w kontrolowaniu państwa mającego problemy ze spełnieniem kryteriów konwergencji.

Po tej krótkiej ilustracji można przejść do omówienia kanałów koordynacji. Koordynacja jest konsekwencją pewnych ustaleń dotyczących polityki. Ilustracją tego mogą być umowy EPA (Umowy o partnerstwie gospodarczym w zakresie handlu i pomocy rozwojowej) zawarte między UE a grupą państw Afryki, Karaibów i Pacyfiku ${ }^{16}$. Kanałem koordynacji jest $\mathrm{w}$ tym przypadku przyjęte rozwiązanie pozwalające kontrolować realizację przyjętych zobowiązań. Kanał ten wynika z członkostwa danego państwa w organizacji lub innych zinstytucjonalizowanych form współpracy międzynarodowej oraz przyjętych zasad kontroli realizacji zobowiązań i wynikających stąd konsekwencji. W warunkach podziału kompetencji w tym zakresie między poszczególne instytucje międzynarodowe w praktyce mamy do czynienia z szeregiem kanałów koordynacji, które wzajemnie się wspierają, począwszy od określenia ogólnych ram, na bardziej szczegółowych rozwiązaniach i częstszej kontroli skończywszy.

\subsection{Podatność na wielopoziomowe zarządzanie}

Podatność danego państwa na rozwiązania wprowadzone w ramach wieloszczeblowego zarządzania jest zdecydowanie zróżnicowana. Przyczyn tego jest wiele. Jednym źródłem jest brak wiedzy o możliwości wykorzystania tego rodzaju „lewarowania”, które wychodzi poza granice danego państwa. Jest to najczęstsza przyczyna braku podatności na rozwiązania przyjęte na poziomie międzynarodowym i ograniczone wyniki jego stosowania. Drugim źródłem jest niepoprawna interpretacja rozwiązań zastosowanych przez poszczególne państwa podczas zabiegów interwencyjnych, które sprzyjały uzyskiwaniu przez zagrożone kryzysem podmioty utraty płynności finansowej (stosowane w ramach m.in. polityki too big to fail). Trzecim powodem ograniczonej skuteczności jest brak konsekwencji w polityce stosowanych kar, egzekwowania wspólnych ustaleń i osiągania docelowych parametrów. Wynika to ze zbyt dużej pobłażliwości i nadmiernej tolerancji wobec łamania wspólnie przyjętych zasad. Czwartym powodem jest brak przygotowania instytucjonalno-prawnego do wykorzystania stworzonych $\mathrm{w}$ ramach umów międzynarodowych warunków stymulowania przemian.

Analiza polityki państwa, które skutecznie wychodzi z kryzysu i powraca do wzrostu oraz tworzenia miejsc pracy, pokazuje, że interwencja nie jest działaniem opartym

${ }^{16}$ K. Kołodziejczyk, Stosunki Unii Europejskiej z grupa państw Afryki, Karaibów i Pacyfiku, Wydawnictwo Rambler, Warszawa 2013. 
na charytatywnym datku, ale jest pożyczką, którą należy zwrócić. Pożyczka taka pomaga restrukturyzować podmiot gospodarczy pod warunkiem, że jest poprawnie w tym celu wykorzystana. Okazywanie zbyt miękkiego serca w takich przypadkach nie tylko ogranicza podatność podmiotu na zmiany, ale przede wszystkim prowadzi państwo (bank) do wzrostu jego ryzyka wynikającego ze wzrostu deficytu i zagrożenia trudnościami zwrotu środków zainwestowanych w plan poprawy.

\subsection{Zarządzanie na szczeblach wewnętrznych państwa a zarządzanie na szczeblach międzynarodowych}

Obok szczebli wewnętrznych w każdym państwie mamy do czynienia ze szczeblami międzynarodowymi zarządzania. Szczeble wewnętrzne stanowią określoną hierarchię, która obejmuje szczebel centralny, regionalny, lokalny. Każdy z wymienionych szczebli działa w sposób subordynowany z wytycznymi ze szczebli wyższych. Do tej hierarchii dodajemy dodatkowo szczeble międzynarodowe. Umiędzynarodowienie procesu zarządzania nie oznacza jednak, że za każdym razem informacja lub środki muszą przechodzić przez wszystkie szczeble koordynacji działań. Międzynarodowe szczeble koordynacji mogą mieć wpływ bezpośredni na szczeble niższe, co uzależnione jest od rozwiązywanego problemu i przyjętej formy jego rozwiązania. Takie działanie pozwala oddolnie rozwikłać wiele kwestii, niemniej jednak wymaga to spełnienia określonych warunków przez jednostki lokalne. Jednym z nich jest przygotowana do tego kadra, drugim - znajomość procedur i istniejących możliwości w tym zakresie, trzecim - determinacja realizacji zakładanych założeń samodzielnie, bez oczekiwania na wytyczne z góry. Ważnym warunkiem powodzenia takiego działania jest również niehamowanie inicjatyw oddolnych.

\subsection{Zarządzanie a interesy globalne, regionalne, subregionalne bilateralne i indywidualne}

W tej części opracowania poszukiwana jest odpowiedź na pytanie, dlaczego państwa o różnych poziomach rozwoju są zainteresowane współpracą międzynarodową, w której jedni tworzą warunki i wspomagają wieloszczeblowe zarządzanie, a inni angażują się w ten proceder?

Wymieniono trzy grupy państw: 1) świat zachodni (trzecia faza rozwoju i faza przejściowa z drugiej do trzeciej), 2) kraje o gospodarkach wschodzących (druga faza rozwoju i faza przejściowa z pierwszej do drugiej), 3) kraje rozwijające się (pierwsza faza rozwoju), które znajdują się na różnych poziomach rozwoju. Każda z tych grup znajduje się na innym poziomie rozwoju, co wpływa na definiowanie interesów 
dotyczących zarówno sfery wewnętrznej, jak i międzynarodowej. Z pewnością oprócz kwestii wewnętrznych można zakładać większe zaangażowanie w rozwiązywanie problemów globalnych, subregionalnych i regionalnych w grupie państw zaliczanych do świata zachodniego niż w przypadku krajów rozwijających się. Niemniej jednak coraz silniej widać zaangażowanie państw wschodzących i rozwijających się $\mathrm{w}$ tworzenie regionalnych grup integracyjnych, czemu sprzyja instytucjonalizacja ich powiązań zewnętrznych przez uczestnictwo w MFW, Banku Światowym i Światowej Organizacji Handlu. Jak wskazuje praktyka, jest to jeden z warunków wieloszczeblowego zarządzania, który umożliwia i sprzyja takiej formie współpracy. Wystarczy przeanalizować warunki członkostwa w tych organizacjach, koncentrację na rozwiązywaniu dzięki spełnieniu tych warunków określonych problemów wewnętrznych, a także specjalizację w ich rozwiązywaniu.

Członkostwo w tych wszystkich organizacjach ma określoną sekwencję, stąd też biorą się określone różnice w liczebności członków. MFW liczy 159 członków, Bank Światowy - 187, a Światowa Organizacja Handlu - 159. Duża różnica między liczbą członków MFW a WTO związana jest z trudnością spełnienia warunków członkostwa oraz przebiegiem negocjacji tych warunków. Przykładowo członkostwo w WTO rozwiązuje kwestie dotyczące liberalizacji gospodarki zarówno w jej kontaktach zewnętrznych, co obejmuje wymianę handlową, usług, przepływ kapitału, własności intelektualnej i obecność państwa w gospodarce. Liczba państw członkowskich MFW nie rośnie tak dynamicznie jak liczba państw należących do WTO. W ostatnich 15 latach do WTO dołączyły takie rynki, jak Chiny, Ukraina, Rosja czy Wietnam. Warto wyjaśnić, że państwa Ameryki Łacińskiej uzyskały członkostwo w WTO, przenosząc się z GATT, podobnie jak większość obecnych państw członkowskich UE (wyjątek stanowi Chorwacja, chociaż b. Jugosławia była członkiem GATT). Państwa powstałe z rozpadu ZSRR zyskały członkostwo w ostatnich latach, podobnie jak to się dzieje z państwami powstałymi z rozpadu b. Jugosławii.

Członkostwo w GATT, a następnie w WTO ma znaczenie, gdyż poprzedza je członkostwo w MFW, a następnie w BŚ, co oznacza zastosowanie np. określonych rozwiązań kursowych, reżimów kursu waluty i kwestii wymienialności. Ma to szczególne znaczenie dla przepływu kapitału i dla wprowadzenia określonych rozwiązań dotyczących konkurencji (handel, stosowanie podobnych rozwiązań dla inwestorów zagranicznych i krajowych czy obecności państwa w gospodarce). Koniecznie w tym miejscu jest wyjaśnienie, że każda umowa regionalna tworząca podstawy do integracji jest wcześniej weryfikowana przez WTO. Zasada ta pozwala wyeliminować ewentualność zagrożeń dyskryminacji państw, które pozostają poza sferą integracji. Ta bezwzględna reguła powoduje, że państwa nie wprowadzają dyskryminacyjnych rozwiązań, respektując przez to dość różnorodne interesy lokalne, narodowe, 
regionalne, subregionalne czy globalne. Jednym z rozwiązań, które to gwarantuje, jest wymóg stosowania KNU (klauzula największego uprzywilejowania). Oznacza ona, że przywileje udzielane jednemu państwu powinny być zagwarantowane innym państwom. Zasada ta nie dotyczy ugrupowań integracyjnych, co oznacza, że jest to jedno $\mathrm{z}$ odstępstw dotyczących potrzeby stosowania niedyskryminacji w grupie państ $w^{17}$. Ugrupowania integracyjne stosują różne rozwiązania (tworząc strefy wolnego handlu lub unie celne), znoszą między sobą bariery dla wymiany handlowej (ostatnio również ograniczeń przepływu kapitału).

Teoria (M. Allais) mówi, że integrować się mogą państwa reprezentujące podobny poziom rozwoju. Nie do końca model taki sprawdził się w praktyce. Sprawdził się w warunkach państw reprezentujących wyższy poziom rozwoju (EWG/UE i EFTA), nie sprawdził się w przypadku integracji państw na równym, ale niskim poziomie rozwoju $\left(\right.$ Mercosur $\left.{ }^{18}\right)$. Prawie w tym samym czasie, kiedy powstała koncepcja M. Allais, podjęto decyzję o utworzeniu NAFTA, a następnie zaakceptowano poszerzenie UE o państwa, których PKB na głowę kształtował się na poziomie 30\% średniej dla państw tego ugrupowania. Wprawdzie obecnie Mercosur wykazuje się pewnymi osiągnięciami zarówno w zakresie procesów pogłębiania integracji (powołanie wspólnego parlamentu), jak i na zewnątrz, niemniej jednak intensywniejsze impulsy dla przemian uzyskałoby w warunkach bliższej współpracy w ramach np. FTAA (strefy wolnego handlu obu Ameryk). Negocjacje stowarzyszenia Mercosur z UE również stanęły w miejscu ${ }^{19}$.

Przyczyn załamania się negocjacji w ramach FTAA i Mercosur można upatrywać w kryzysie 2008/2009, niemniej negocjacje utknęły wcześniej w martwym punkcie, zanim załamanie światowej koniunktury stało się zjawiskiem powszechnie odczuwalnym. Z pewnością państwa Ameryki Łacińskiej czują się pewniejsze w swych decyzjach dotyczących liberalizacji, przeprowadzając ją zgodnie z koncepcją M. Allais, co oznacza najpierw integrację regionalną między państwami reprezentującymi podobny poziom rozwoju (państwa Mercosur), a dopiero w następnym kroku - integrację z NAFTA i UE. Bez względu na sekwencyjność wymienionych procesów prze-

${ }_{17}$ Most Favoured Nation Clauses - No favoured view how they should be interpreted, Kluwer Arbitration Blog. 2011 CPRJ Institute Award Winner Outstanding Electronic Media, http://kluwerarbitrationblog.com/ blog/2011/07/25/most-favoured-nation-clauses-\%E2\%80\%93-no-favoured-view-on-how-they-should-beinterpreted/, dostęp 30.08.2013.

18 Unia celna między Argentyną, Brazylią, Paragwajem, Urugwajem i Wenezuelą. Członkostwo stowarzyszone mają: Boliwia, Chile, Kolumbia, Ekwador, Gujana, Peru, Surinam. Obserwatorami są Meksyk i Nowa Zelandia.

${ }^{19}$ C. Kirkpatrick, C. George [główni autorzy], Trade Sustainability Impact Assessment (SIA) of Association Agreement under Negotiation between the European Community and Mercosur. Final Overview Trade SIA Mercosur. Final Report. Revised version, Manchester, March 2009. 
biegają one zgodnie z modelem integracji opracowanym przez B. Balassę ${ }^{20}$. Państwa reprezentujące niższy poziom rozwoju w kontaktach z rynkami wysoko rozwiniętymi są na ogół bardzo ostrożne, o czym decyduje ich kolonialna przeszłość. Niemniej jednak ekonomistom jest znana teoria o stymulowaniu rozwoju przez wymianę handlową czy zasada mnożnika i wynikające $z$ niej zmiany zachodzące w poziomie dobrobytu. Teorie te często prowadziły do poszukiwania lokalnych rozwiązań, zgodnie z koncepcjami lokalnymi w regionie (produkcja antyeksportowa, produkcja proeksportowa), co jednak ostatecznie doprowadziło do stopniowego poparcia koncepcji włączania się do międzynarodowego podziału pracy i kształtowania go zgodnie z interesem państw reprezentujących niższy poziom rozwoju ${ }^{21}$. Praktyka dowodzi, że mimo obaw przez integracją państw, które reprezentują zróżnicowany poziom rozwoju, rozwiązanie takie jest korzystne zarówno dla państw wysoko rozwiniętych, jak i reprezentujących niższy poziom rozwoju. Niemniej jednak decyzje dotyczące integracji państw niżej rozwiniętych z zaliczanymi do grupy rozwiniętych muszą być poprzedzone integracją regionalną państw na tym samym poziomie. Takie rozwiązanie znajduje uzasadnienie w argumentacji już nie tyle teoretycznej, czy płynącej z doświadczenia praktycznego, jest natomiast skutkiem wieloletniego obowiązywania teorii, które następnie nie znalazły potwierdzenia w praktyce, niemniej jednak głęboko utkwiły w pamięci polityków i ich wyborców. Tym samym wspiera się następującą kolejność:

- instytucjonalizacja stosunków zewnętrznych tam, gdzie jeszcze jej nie ma; na tym etapie członkostwo w WTO warunkuje pewne rozwiązania, które określa się jako globalne, gdyż dotyczą wszystkich liczących się na rynku światowym eksporterów;

- tworzenie stref wolnego handlu w regionach, czemu często towarzyszy próba podjęcia negocjacji prowadzących do stowarzyszenia z UE;

- powrót do negocjacji w sprawie utworzenia strefy wolnego handlu (umowy stowarzyszenia) z UE.

Warto wyjaśnić, że integracja i towarzysząca jej liberalizacja wpływają zarówno korzystnie, jak i niekorzystnie na społeczeństwa objęte tymi procesami. Z jednej strony tworzą warunki do rozwoju i wzrostu dobrobytu, z drugiej zaś są źródłem działań o charakterze nacjonalistycznym, ksenofobicznym w tej części społeczeństwa, która ponosi koszty tych procesów (restrukturyzacji gospodarki, podnoszenia efektywności, rosnących wymogów edukacyjnych, organizacyjnych itp.). Negatywne efekty integracji są odczuwalne zwłaszcza wówczas, gdy społeczeństwo i instytucje

20 B. Balassa, The Theory of Economic Integration, Allen \& Unwin, New York 1965, s. 163 i n.

${ }^{21}$ K. Kłosiński, Ameryka Łacińska w poszukiwaniu konsensusu, KUL, Lublin 2013. 
państwowe są źle przygotowane do liberalizacji ${ }^{22}$. Ruchy te są prowokowane z jednej strony zjawiskiem umiędzynarodowienia i procesów zacierania się różnic między poszczególnymi nacjami, z drugiej zaś może to być protest przeciwko ubocznym kosztom tego procesu, jak zmiany klimatyczne, wzrost zanieczyszczeń środowiska czy alienacja społeczna, wyłączenie ekonomiczne, kulturowe itp.

\section{Podsumowanie}

Wielopoziomowe zarządzanie oraz sekwencyjność posunięć dotyczących tworzenia warunków do rozwoju gospodarki państw czy ich grup jest faktem w stosunkach międzynarodowych. Sprzyjają tym rozwiązaniom uzupełniające się interesy grup państw, co ma znaczenie w sytuacji, gdy egoizm realizacji wielu z tych interesów jest temperowany, żeby nie powiedzieć kontrolowany przez prawo międzynarodowe i tworzące je instytucje międzynarodowe.

W ograniczonym stopniu wiedza na temat wielopoziomowego zarządzania, sekwencyjności rozwoju oraz możliwości z tym związanych dla gospodarek rozwiniętych i rozwijających się znalazła odbicie w publikacjach oraz skutecznych rozwiązaniach opartych na wspomnianych mechanizmach w praktyce. Na ogół publikacje omawiające ten wycinek stosunków międzynarodowych pokazują niską przydatność tego rodzaju instrumentów, które zostały stworzone dla celów rozwoju i są dość powszechnie wdrażane, choć ich skuteczność jest dość ograniczona.

Do najważniejszych ograniczeń w zakresie skutecznego stosowania wielopoziomowego zarządzania, sekwencyjności rozwoju i jego zróżnicowania można zaliczyć:

- brak wiedzy o możliwości wykorzystania stworzonych w ramach umów międzynarodowych mechanizmów wielopoziomowego zarządzania;

- ograniczoną wiedzę na temat kanałów, przez które rozwiązania te mogą wywierać wpływ;

- ograniczenia w przygotowaniu prawnym, instytucjonalnym oraz personelu do ich zastosowania i podniesienia efektów zastosowanych w tym zakresie rozwiązań;

- przewagę starej wiedzy o dominacji państw wysoko rozwiniętych, których działania postrzegane są jako nowe sposoby podejmowania prób podporządkowania tworzonych więzi i wykorzystania ich w formie neokolonialnych więzi prowadzących

22 Złe przygotowanie do liberalizacji to niska efektywność działania instytucji i niski poziom edukacji, w którym dominuje automatyzm, uczenie się na pamięć, brak podstaw do myślenia, kojarzenia, twórczych i kreatywnych rozwiązań oraz rozumienia świata. Ważnym ogniwem wspierającym właściwy kierunek przemian jest infrastruktura telekomunikacyjna, w tym internet. 
do podporządkowania państw reprezentujących niższy poziom rozwoju partykularnym interesom państw wysoko rozwiniętych.

Podniesienie skuteczności dostępnych form współpracy wymaga nowego podejścia do budowania zaufania, przygotowania lokalnej kadry, wspierania w państwach rozwijających się procesów demokratyzacji, rozwoju edukacji i dążenia do tworzenia warunków umożliwiających ich awans rozwojowy i ekonomiczno-społeczny.

W sumie można powiedzieć, że warunki zostały stworzone do wykorzystania sekwencyjności rozwoju i wieloszczeblowego zarządzania zmianami oraz rozwojem, ale nie towarzyszy temu symetria zrozumienia ich wykorzystania do celów rozwoju. Praktyka pokazuje, że produkcja „towaru” i jego oferta na rynku często nie jest warunkiem wystarczającym, aby powstał symetrycznie do takiej oferty popyt na ten towar. Popyt ten wymaga kształtowania. Podobnie można oceniać warunki do rozwoju stworzone przez państwa wysoko rozwinięte oraz organizacje międzynarodowe, przy braku lub ograniczonym zapotrzebowaniu na takie rozwiązania, a także pewnej bezradności korzystania z udostępnionych instrumentów i mechanizmów. Sfera ta wyraźnie jest zaniedbana i wymaga określonych działań, skupionych na tworzeniu zapotrzebowania na wieloszczeblowe zarządzanie, i wskazywania związanych $\mathrm{z}$ tym procesem możliwości.

\section{Sequencing of development and multilevel management of the economy with emphasis on the developing countries}

The article shows possibilities of economic processes management in each economy, dividing them into internal methods and external methods. The later embrace conditions created by international environment as well as international organizations and relations established with them. Such management is strongly dependent on diversification of development of particular groups of economies, it takes into account national interests of different groups of economies and national, regional and global interests and differences among them. The concept is also strongly linked to stage of development of external institutional ties of each state. A separate part of the study is devoted to transmission channels which play an important role in helping to introduce certain solutions practiced and tested in other democracies. The subject covered in the article illustrates that only a limited number of countries make full use of the possibilities which were created by conditions of differentiated development and multilevel management, which creates an important component of the compound system, supporting it strongly. The conclusion of the article draws attention to the need of knowledge acquisition 
concerning sequencing of development and multilevel management of economic processes in each economy.

Keywords: multilevel management, sequencing, development, developing economies, rising economies, management channel, internal management, external management

\section{Le séquençage du développement et la gestion à plusieurs niveaux de l'économie avec un accent particulier sur les pays en développement}

Larticle montre les possibilités de la gestion des processus économiques au niveau de chaque pays, en distinguant les méthodes internes et externes. Les méthodes externes tiennent compte de l'environnement international et des conditions créées par les organisations internationaux. L'auteur souligne l'importance d'une telle gestion, en présentant l'importance de différencier le développement de certains groupes de pays et en montrant leurs intérêts nationaux, régionaux et mondiaux, ainsi que l'institutionnalisation de leurs relations extérieures. Une autre partie de l'article est consacrée aux canaux de transmission des solutions spécifiques du système international sur les marchés nationaux. Le sujet abordé dans l'article montre qu'il y a peu de pays qui profitent vraiment des possibilités créées dans le cadre du développment séquentiel dont un élément essentiel est la gestion à plusieurs niveaux. La conclusion de l'article attire l'attention sur la nécessité de l'acquisition des connaissances sur le séquençage du développement et de la gestion à plusieurs niveaux des processus économiques dans chaque économie.

Mots-clés: la gestion à plusieurs niveaux, le séquençage, le développement, les économies en développement, les économies émergentes, le canal de gestion, la gestion interne, la gestion externe

\section{Последовательность развития и многоуровневое управление экономикой - казус развивающихся стран}

В статье указаны возможности управления экономическими процессами в экономике страны, разделяя их на внутренне и внешние методы. Последние относятся к условиям созданным международной средой, а также международными организациями и сложившимся с ними отношениями. Такое 
управление сильно зависит от диверсификации развития отдельных групп стран, их национальных, региональных и глобальных интересов и различий между ними. Эта концепция также тесно связана с развитием внешних институциональных связей стран. Отдельная часть исследования посвящена каналом управления, которые играют важную роль во введении определенных решений, практикуемых и проверенных в других демократических государствах. Исследование показывает, что лишь незначительное число стран использует в полной мере возможности созданные дифференцированным развитием и многоуровневым управлением. В статье обращается внимание на необходимость приобретения знаний о последовательности развития и о многоуровневом управлении экономическими процессами в экономике.

Ключевые слова: многоуровневое управление, последовательность, развитие, развивающиеся экономики, рост экономики, канал управления, внутреннее управление, внешнее управление 